\title{
Estimating Sound Seeds per Cone in White Spruce
}

by

\author{
W.H. Fogal ${ }^{1}$ and I.S. Alemdag ${ }^{1}$
}

\begin{abstract}
White spruce cones were collected near Petawawa, Sudbury, and Oakville, Ontario during the 1982 and 1984 crop years. Cones were used to examine several regression models for estimating the number of sound seeds per cone as a function of seeds per cone section, cone length, and/or diameter. For the simplest models, using only one independent variable, highest coefficients of determination $\left(R^{2}\right)$ were found with sound seed per section. A multiple regression model, including all three independent variables and their interactions, was identified. It provided higher coefficients of determination than the model using sound seed per cone section as a single independent variable but did not provide much more precision for estimating sound seeds per cone. Regressions were specific for locations and crop years.
\end{abstract}

\section{Résumé}

Des cônes d'épinette blanche ont été cueillis près de Petawawa, de Sudbury et d'Oakville, en Ontario, au cours des années semencières 1982 et 1984. Ces cônes ont servi à l'examen de plusieurs modèles de régression permettant d'estimer le nombre de graines saines par cône en fonction des graines par section de cône, de la longueur des cônes et(ou) du diamètre de ceux-ci. Dans le cas des modèles les plus simples n'utilisant qu'une seule variable indépendante, les coefficients de détermination $\left(R^{2}\right)$ les plus élevés ont été obtenus pour le modèle reposant sur le nombre de graines saines par section. Un modèle de régression multiple intégrant les trois variables indépendantes ainsi que leurs interactions a donné des coefficients de détermination plus élevés que ce modèle, mais il n'apportait pas une précision beaucoup plus élevée. Les régressions sont spécifiques aux endroits et aux années de récolte.

\section{Introduction}

Evaluating cone quality is an important step in seed procurement planning, and counting the number of filled seeds on the cut surface of a longitudinal cone section is a standard procedure used by field foresters for estimating seed yields and determining the collectability of conifer cone crops (Albricht and Birzins 1982, Alden 1985, Asher 1964, Calvert 1978, Dobbs et al. 1976, McLemore 1962, Schmid et al. 1985). Examining the cut surface of a cone section has also been used to estimate seed losses by insects (Johnson and Heikkenen 1958, Demars 1964) and for assessing the efficacy of insecticides for preventing damage and increasing yields.

In studies aimed at finding control measures for cone and seed insects of white spruce (Picea glauca [Moench] Voss), we examined the cut surface of cone sections for evidence of damage by insects and counted the numbers of sound seeds (Fogal and Lopushanski 1989, Fogal et al. 1986). The question arises whether or not the number of sound seeds per cone section is a valid predictor of the number of seeds per cone. Good correlations between seeds per cone section and total seeds per cone have been observed for white spruce (Albricht and Birzins 1982) and some southern pines (Pinus palustris Mill; P. elliottii Engelm.; and $P$. taeda L.) (McLemore 1982, Asher 1964) but for ponderosa pine (Pinus ponderosa Laws.) good correlations were found in some locations but not others (Schmid et al. 1985).

In this investigation cone data from three white spruce plantations were examined with several regression models to determine whether seed counts per section are indeed correlated with seeds per cone, whether cone length and diameter along with seeds per cone section can improve estimates of seeds per cone, and whether relationships differ with location and crop year for white spruce.

'Petawawa National Forestry Institute, Forestry Canada, Chalk River, Ontario KOJ 1 JO

\section{Study Locations}

This study was based upon data collected from plantations in three widely separated locations. One plantation, located in Esquesing township near Oakville $\left(43^{\circ} 35^{\prime} \mathrm{N}\right.$; $79^{\circ} 49^{\prime} \mathrm{W}$ ), is part of the Halton County Forest managed by the Cambridge District of the Ontario Ministry of Natural Resources. In 1982 the trees were 28 years old, had a mean height of $5.1 \pm 0.1 \mathrm{~m}$, a mean $\mathrm{DBH}$ of $15.0 \pm 1.9 \mathrm{~cm}$, and were spaced $1.8 \times 3.7 \mathrm{~m}$ apart. A second plantation was located in Burwash township on land managed by the Sudbury District of the Ontario Ministry of Natural Resources $\left(46^{\circ} 17^{\prime} \mathrm{N}\right.$; $\left.80^{\circ} 48^{\prime} \mathrm{W}\right)$. Spacing was $1.8 \times 1.8 \mathrm{~m}$, trees were 23 years old, had a mean hight of $5.2 \pm 0.1 \mathrm{~m}$, and DBH of $10.3 \pm 0.5$ $\mathrm{cm}$. Several plantations were sampled in the Pembroke District on land administered by the Petawawa National Fore-

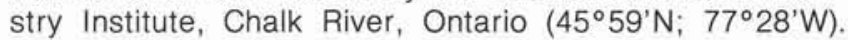
Spacing of the plantations was $1.8 \times 1.8 \mathrm{~m}$, trees ranged in age from 19-29 years, and DBH ranged from 7 to $17 \mathrm{~cm}$ with a mean of $12.6 \pm 0.68 \mathrm{~cm}$.

\section{Data and Data Analyses}

Seed counts were made on 10 cones from each of 20 trees at each location. Cones were collected July 19, 1982 at Oakville; July 21, 1982 and July 18, 1984 at Sudbury; and July 25, 1982 and July 23, 1984 at Petawawa. Length (L) and maximum diameter (D) of each cone were determined in millimetres. The number of sound seeds (seeds with a welldeveloped megagametophyte) per section (N) were counted on the cut face of one of the halves of each cone bisected logitudinally through its axis. The number of sound seeds per cone (NSC) were determined after extraction. Cones were dried at $40^{\circ} \mathrm{C}$ for 24 hours in a forced-draft oven, and seeds from each cone (both halves) were extracted by hand dissection. Sound seeds were identified by cutting and then counted. 


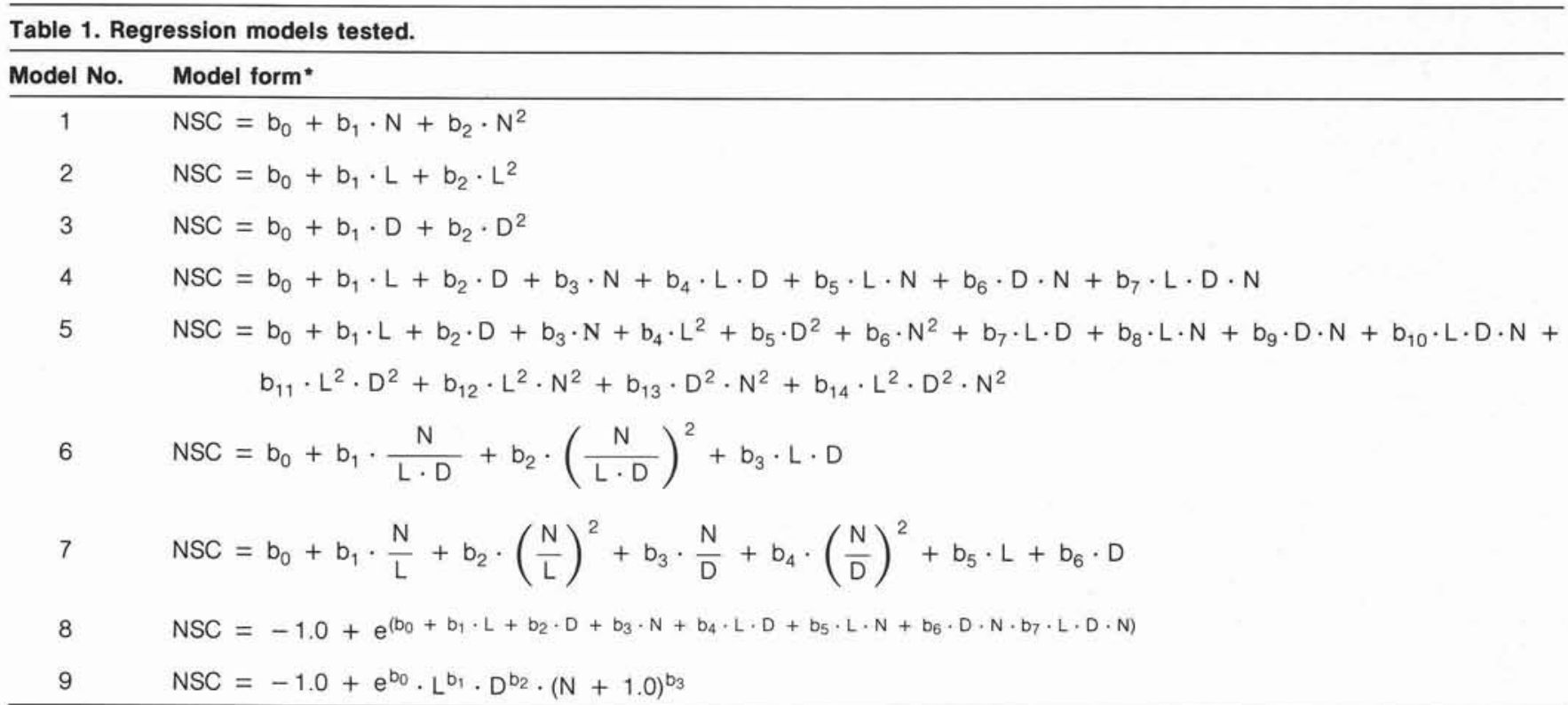

${ }^{\star} \mathrm{NSC}=$ Number of sound seeds per cone $\quad \mathrm{L}=$ Cone length $(\mathrm{mm})$

$\mathrm{N}=$ Number of sound seeds per section $\quad \mathrm{D}=$ Cone diameter $(\mathrm{mm})$

Means and coefficients of variation were calculated for each of the four variables for each location and crop year. Untransformed data of seeds per cone were subjected to analyses of variance to compare locations and years. Scattergrams were prepared for each location and year to visually assess possible relationships between number of sound seeds per cone and the independent variables of number of sound seeds per section, cone length, and diameter. Several mathematical models were used to estimate the number of sound seeds per cone as a function of N, L, and D. Nine models were tested (Table 1). The first three use only one independent variable to estimate NSC. Model 4 includes all three independent variables and their interactions whereas Model 5 includes quadratic terms. The next two models use expressions derived from the independent variables, including the ratio of number of sound seeds per section to the product of section length times width (an approximation of number of seeds per section area) (Model 6), or seeds per unit of cone length and cone diameter (Model 7). Models 8 and 9 are exponential models.

Data of the five combinations of locations and years were fitted independently into these test models, employing the linear regression analysis technique. When running Models 8 and 9 . logarithmic transformations were used after adding +1.0 to both sides of the equation to obtain the logarithm of NSC when it was zero. After these nine models were used with each set of data their performances were evaluated, first by their multiple coefficient of determination $\left(R^{2}\right)$, and standard error of estimate as a per cent of the means (SEE \%), and secondly by examining plots of estimated values of sound seeds per cone against seeds per section for different cone diameters and lengths. For the untrans formed models 8 and 9 , fit index $(\mathrm{FI})$ values were calculated for comparison with the $\mathrm{R}^{2}$ values of the other transformed models. Fit index is a statistical measure to be used in place of $\mathrm{R}^{2}$ when untransformed and transformed models for the same predicted variable are compared within one group (Alemdag 1986).

The accuracy of models at each location and year for different sampling regimes was tested by chi-square analysis (Freese 1960). Possible differences among regressions for different locations and years were tested by analysis of variance (SAS Institute Inc. 1985).

\section{Results and Discussion}

For the three locations and both crop years the number of sound seeds per cone varied from 0 to 162, and sound seeds per cone section varied from 0 to 29 (Table 2). Thus,

Table 2. Statistics of the observed data.

Location $\quad$ Year $\begin{gathered}\text { Number of } \\ \text { observations } \\ \mathbf{n}\end{gathered} \quad$ Mean Range $\quad \begin{aligned} & \text { CV } \\ & (\%)\end{aligned}$

\begin{tabular}{llll} 
Location & Year & $\mathbf{n}$ & Mean \\
\hline
\end{tabular}

$\begin{array}{llllll}\text { Petawawa } & 1982 & 198 & 55 & 2-162 & 61 \\ \text { Petawawa } & 1984 & 200 & 62 & 0-114 & 35 \\ \text { Sudbury } & 1982 & 200 & 50 & 2-99 & 40 \\ \text { Sudbury } & 1984 & 199 & 46 & 7-89 & 39 \\ \text { Oakville } & 1982 & 182 & 61 & 0-152 & 48\end{array}$

(b) Number of sound seeds per section

$\begin{array}{llrrrr}\text { Petawawa } & 1982 & 198 & 9 & 0-29 & 67 \\ \text { Petawawa } & 1984 & 200 & 10 & 0-24 & 51 \\ \text { Sudbury } & 1982 & 200 & 8 & 0-22 & 60 \\ \text { Sudbury } & 1984 & 199 & 10 & 0-23 & 46 \\ \text { Oakville } & 1982 & 182 & 7 & 0-19 & 68\end{array}$

Oakville 1982

(c) Cone length $(\mathrm{mm})$

$\begin{array}{llllll}\text { Petawawa } & 1982 & 198 & 43 & 22-66 & 19 \\ \text { Petawawa } & 1984 & 200 & 42 & 24-58 & 17 \\ \text { Sudbury } & 1982 & 200 & 42 & 15-60 & 18 \\ \text { Sudbury } & 1984 & 199 & 39 & 20-62 & 21 \\ \text { Oakville } & 1982 & 182 & 47 & 26-71 & 17\end{array}$

(d) Cone diameter $(\mathrm{mm})$

\begin{tabular}{lrrrrr} 
Petawawa & 1982 & 198 & 12 & $6-16$ & 13 \\
Petawawa & 1984 & 200 & 11 & $8-16$ & 12 \\
Sudbury & 1982 & 200 & 12 & $9-16$ & 10 \\
Sudbury & 1984 & 199 & 11 & $7-14$ & 11 \\
Oakville & 1982 & 182 & 12 & $9-15$ & 9 \\
\hline
\end{tabular}

${ }^{\star}$ Coefficient of variation $=$ standard deviation/arithmetic mean. 
coefficients of variation were relatively high for these two variables. The coefficients of variation for cone length and width were considerably smaller. Analyses of variance on the numbers of sound seeds per cone revealed statistically significant differences between the two crop years at Petawawa $(P=0.01)$ and Sudbury $(P=0.05)$. There were no differences among locations in 1982 but, in 1984, Sudbury and Petawawa values were significantly different $(P=0.01)$.

A wide range of distribution of seeds per cone over the number of seeds per cone section, cone length, and cone diameter was observed for all locations and years. Scattergrams of the observed data from Petawawa for 1982 are typical (Figure 1). A slight curvilinearity of seeds per cone over

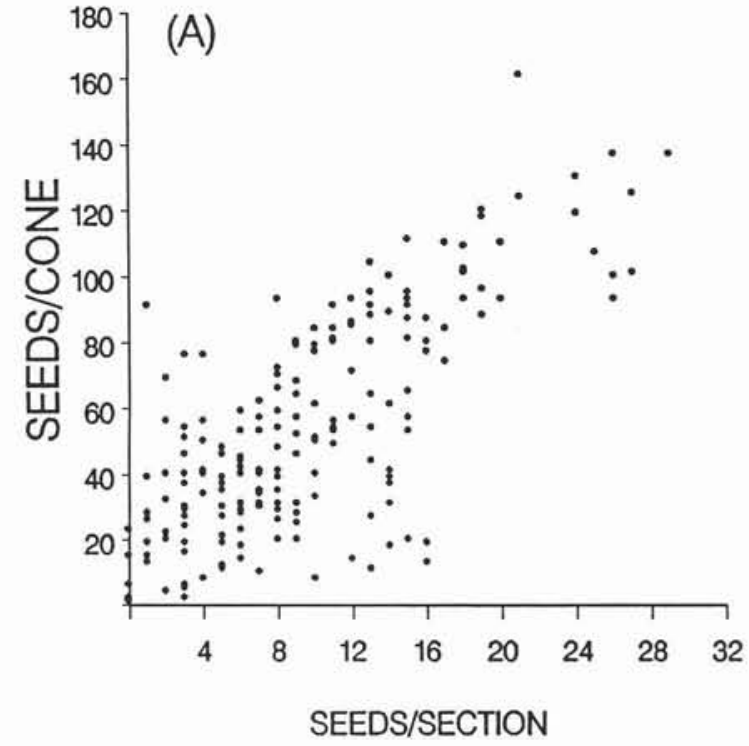

(B)

medels were unrealistic and, therefore, unacceptable. This situation was verified by visual examination after plotting these estimated NSC values over $L$ for different $\mathrm{N}$ classes. Models 8 and 9 produced insignificant $\mathrm{R}^{2}$ values in most cases.

Significant $R^{2}$ values for Model 4 indicate that 46 to $71 \%$ of the variation in number of sound seeds per cone is due to variation in number of sound seeds per cone section, cone length, and cone width. Coefficients for Model 1 indicate that 32 to $70 \%$ of variation in number of sound seeds per cone can be explained by the number of sound seeds per cone section alone. This suggests that addition of cone diameter and length to the regression does not provide a marked increase

Figure 1. Scattergrams for observed data from Petawawa 1982 showing distribution of the number of seeds per cone in relation to (A) number of seeds per section, (B) cone length, and (C) one diameter.

seeds per cone section was detected; nonetheless, straight line relationships appeared to fit the data reasonably well. For the simplest possible linear models, using only one independent variable, coefficients of determination $\left(R^{2}\right)$ for seeds per section (Model 1) tended to be higher than those for length (Model 2). They were highly significant for all locations and years (Table 3 ). Much lower $R^{2}$ values were observed with diameter as the independent variable (Model 3 ) and they were significant for four out of the five cases. Highest $R^{2}$ values were produced with Models 4,5, and 7 which employed all three independent variables. Other models resulted in smaller $\mathrm{R}^{2}$ values. Model 5 for the locations and years of Sudbury 1982, Sudbury 1984, and Oakville 1982, and Model 7 for the locations and years of Petawawa 1982 and Petawawa 1984 produced somewhat higher $R^{2}$ values, but estimates of sound in precision for predicting sound seeds per cone. In fact, both models provided very accurate estimates of the average number of sound seeds per cone for each location and sample year (Table 4) using the composite data set of 10 cones from each of 20 trees for each location.

Chi-square analysis to test the accuracy of the models for estimating seeds per cone within a $\pm 5 \%$ level of error (Freese 1960), for a particular location and year, indicated that both models were accurate $(P=0.05)$ for data sets containing samples of five or 10 cones from 20 trees. However, Model 1 did not accurately estimate seeds per cone when a sample of two cones from 20 trees was used, whereas Model 4 did. Neither model was accurate when data sets from five or 10 trees were used. The results of this test confirrn that Model 4

Table 3. Coefficients of determination $\left(\mathrm{R}^{2}\right)$ for all regression models at different locations and years.

\begin{tabular}{|c|c|c|c|c|c|c|c|c|c|c|}
\hline \multirow[b]{2}{*}{ Location } & \multirow[b]{2}{*}{ Year } & \multicolumn{9}{|c|}{ Model } \\
\hline & & 1 & 2 & 3 & 4 & 5 & 6 & 7 & 8 & 9 \\
\hline Petawawa & 1982 & $.563^{\star \star}$ & $.466^{\star \star}$ & $.081^{\star \star}$ & $.623^{\star \star}$ & $.623^{\star \star}$ & $.587^{\star \star}$ & $.628^{\star \star}$ & .585 & .587 \\
\hline Sudbury & 1982 & $.357^{\star \star}$ & $.456^{\star \star}$ & $.168^{\star \star}$ & $.503^{\star \star}$ & $.553^{\star}$ & $.520^{\star *}$ & $.532^{\star \star}$ & $.534^{\star}$ & .484 \\
\hline Sudbury & 1984 & $.696^{\star \star}$ & $.145^{\star \star}$ & .019 & $.711^{\star *}$ & $.720^{\star}$ & $639^{\star \star}$ & $.690^{\star \star}$ & .639 & .691 \\
\hline Oakville & 1982 & $.320^{\star \star}$ & $.398^{\star \star}$ & $.228^{\star \star}$ & $.455^{\star \star}$ & $.518^{\star \star}$ & $.452^{\star \star}$ & $.477^{\star}$ & $.445^{\star \star}$ & $.354^{\star}$ \\
\hline
\end{tabular}

Significant at $\mathrm{P}<0.01^{* *}$ or $\mathrm{P}<0.05^{\star}$ 
Table 4. Mean values of observed seeds per cone and estimated seeds per cone with Models 1 and 4 for each location and year.

\begin{tabular}{lcccc}
\hline & & & \multicolumn{2}{c}{$\begin{array}{c}\text { Mean estimated } \\
\text { NSC }\end{array}$} \\
\cline { 4 - 5 } Location & Year & $\begin{array}{c}\text { Mean observed } \\
\text { NSC }\end{array}$ & Model 1 & Model 4 \\
\hline Petawawa & 1982 & 55 & 55 & 55 \\
Petawawa & 1984 & 63 & 62 & 63 \\
Sudbury & 1982 & 50 & 51 & 50 \\
Sudbury & 1984 & 46 & 47 & 46 \\
Oakville & 1982 & 61 & 61 & 61 \\
\hline
\end{tabular}

provides little advantage over Model 1 when sufficiently large numbers of cones and trees are sampled.

For equations derived from Model 1 the constants and regression coefficients are all positive but vary considerably and the equations of Model 4 have different numbers of significant terms and different constants with different locations and years (Table 5). This suggests that there may be differences among locations and years in the relationships among seeds per cone and the independent variables of seeds per section, cone length, and diameter. For Model 1, analysis of variance F-tests indicated that regressions for each location within years were significantly different $(P=0.01)$ and regressions for each year at a particular location were different as well $(P=0.05)$. For Model 4 , differences among locations within years and among years for particular locations were also highly significant $(P=0.01)$. Such differences may reflect influences of the tree's environment and/or genetic characteristics on cone and seed development.

Megasporophylls of spruces are spirally arranged around a central axis within female strobili, with each megasporophyll bearing two megaspores or seeds at its base (Schopmeyer 1974). The number of spirals per cone characterizes species of spruces (Daubenmire 1968) and the number of seeds per cone will depend upon the pitch and diameter of the spirals and length of the cones. Length, seed weights, and other morphological features of white spruce cones are under strong genetic control and do not differ greatly among seed zones or stands within a seed zone; most of the variation in these characters is due to differences among cones within trees and among trees within populations (Khalil 1974). Thus, the slope and level of regressions of seeds per cone as a function of seeds per section for individual trees in the same stand are likely to vary. Indeed, such differences have been demonstrated for a pine (Pinus palustris Mill) (McLemore 1962). Similar differences among white spruce trees within a stand might account for the better fit between the actual number of seeds for each location and year and the estimates using data sets from 20 trees by comparison with estimates based on five or 10 trees. Differences in seeds per cone among crop years and locations can be expected. In spruces many potential seeds can be lost as a result of poor pollination success, seed abortion (Owens and Blake 1985), and insect feeding activity (Tripp and Hedlin 1956). These factors are strongly influenced by variation in environmental conditions among years and locations. It is possible that differences in seeds per cone among years and locations could influence the relationships among this variable and the independent variable of seeds per section, cone length, and cone width, making them unique for each location and year. This suggests that a single regression over a wide area or for one year is not a highly accurate predictor for local situations over successive years. Within a given year and location, however, counts of seeds per cone section provide a good relative estimate of seeds per cone if a suitable sample is taken.

\section{Conclusions}

For white spruce, the number of sound seeds per cone can be estimated by means of regression analysis. A simple linear model using number of sound seeds per cone as a function of the number of sound seeds per section provides highly significant coefficients of determination. A linear model employing seeds per section, cone length, and diameter as independent variables provides slightly higher coefficients of determination and, depending on sample size, may increase accuracy for predicting seeds per cone. Regressions were specific for locations and crop years.

Table 5. Regression equations generated for data from different locations and years using Models 1 and 4 .

\begin{tabular}{|c|c|c|c|}
\hline Location & Year & Model & Regression equations \\
\hline Petawawa & 1982 & $\begin{array}{l}1 \\
4\end{array}$ & $\begin{array}{l}\text { NSC }=17+4.0 N \\
\text { NSC }=-6.5+5.9 \cdot 10^{-2} \cdot N \cdot L+0.8 \cdot L\end{array}$ \\
\hline Petawawa & 1984 & $\begin{array}{l}1 \\
4\end{array}$ & $\begin{array}{l}\text { NSC }=35+2.8 \mathrm{~N} \\
\text { NSC }=-6.3-2.9 \cdot 10^{-4} \cdot N \cdot L \cdot D+1.2 \cdot L+2.1 \cdot N\end{array}$ \\
\hline Sudbury & 1982 & $\begin{array}{l}1 \\
4\end{array}$ & $\begin{array}{l}\mathrm{NSC}=32+2.3 \mathrm{~N} \\
\mathrm{NSC}=17.8+1.4 \cdot \mathrm{L}+1.1 \cdot \mathrm{N}\end{array}$ \\
\hline Sudbury & 1984 & $\begin{array}{l}1 \\
4\end{array}$ & $\begin{array}{l}\text { NSC }=14+3.2 \mathrm{~N} \\
\mathrm{NSC}=40.8+2.1 \cdot \mathrm{N}-2.4 \cdot \mathrm{D}+2.0 \cdot 10^{-3} \cdot \mathrm{N} \cdot \mathrm{L} \cdot \mathrm{D}\end{array}$ \\
\hline Oakville & 1982 & $\begin{array}{l}1 \\
4\end{array}$ & $\begin{array}{l}\mathrm{NSC}=37+3.7 \mathrm{~N} \\
\mathrm{NSC}=5.6+4.0 \cdot 10^{-3} \cdot \mathrm{N} \cdot \mathrm{L} \cdot \mathrm{D}+7.4 \cdot 10^{-2} \cdot \mathrm{L} \cdot \mathrm{D}\end{array}$ \\
\hline
\end{tabular}

\section{Acknowledgement}

We are grateful to Mr. S. M. Lopushanski for making cone collections and seed counts, and to Mrs. L. R. Roy for doing the computer work. Mr. C. E. Van Wagner and Dr. D. Burgess provided useful comments and suggestions for improving this report.

\section{References}

Albricht, M. and P. J. Birzins. 1982. Relationships between filled seeds per halfcut and filled seeds per cone in interior spruce. Tree Planters Notes 33: 35.

Alden, J. 1985. Biology and managment of white spruce seed crops for reforestation in subarctic taiga forests. USDA For. Serv. and Univ. Alaska. Bull 69. 
Alemdag, I. S. 1986. Estimating ovendry mass of trembling aspen and white birch using measurements from aerial photographs. Can. J. For. Res. 16: 163-165.

Asher, W. C. 1964. A formula for estimating slash pine seed yields. J. For. 62: 37-39.

Calvert, R. F. 1978. A method to evaluate white spruce cone crops. For. Chron. 54: 88-91.

Daubenmire, R. 1967. Some geographic variations in Picea stichensis and their ecologic interpretation. Can. J. Bot. 46: 787-798.

Demars, C. J. 1964. Predicting insect-caused damage to Douglas-fir seed from samples of young cones. USDA For. Serv. Res. Note PSW-40.

Dobbs, R. C., D. G. W. Edwards, J. Konishi, D. Wallinger. 1976. Guide to collecting cones of BC conifers. BC Forest Serv./Can. For. Serv. Joint Rep. No. 3.

Fogal, W. H., S. M. Lopushanski. 1989. Stem incorporation of systemic insecticides to protect white spruce seed trees. For. Chron. In press.

Fogal, W. H., G. D. Thurston, G. D. Chant. 1986. Reducing seed losses to insects by treating white spruce conelets with conidiospores of Beauveria bassiana. Proc. Ent. Soc. Ont. 117: 95-98.

Freese, F. 1960. Testing accuracy. For. Sci. 6: 139-145.

Johnson, N. E., J. H. Heikkenen. 1958. Damage to the seed of Douglasfir by the Douglas-fir cone midge. For Sci. 4: 274-282.

Khalil, M. A. K. 1974. Genetics of cone morphology in white spruce (Picea glauca). Can. J. Bot. 52: 15-21.

McLemore, B. F. 1962. Predicting seed yields of southern pine cones. J. For. 60: 639-641.

Owens, J. N., M. D. Blake. 1985. Forest tree seed production: a review of literature and recommendations for future research. Can. For. Serv. Inf. Rep. PI-X-53.

SAS Institute Inc. 1985. SAS User's guide: Statistics, version 5 edition. Cary, NC.

Schmid, J. M., S. A. Mata, J. C. Mitchell. 1985. Estimating sound seeds in Ponderosa pine cones from half-face counts. USDA For. Serv. Res. Note RM-459.

Schopmeyer, C. S. 1974. Seeds of Woody Plants in the United States. Agric. Handbook No. 450. USDA For. Serv., Washington, D. C.

Tripp, H. A., A.F. Hedlin. 1956. An ecological study and damage appraisal of white spruce cone insects. For. Chron. 32: 400-410.

\section{La recherche en foresterie MARKETPLACE Les résultats en action}

Le 22 et le 23 Novembre, The Royal York Hotel, Toronto, Ontario

- PLUS DE 150 PRÉSENTATIONS STATIQUES SUR LA RECHERCHE

- PLUS DE 50 EXHIBITIONS COMMERCIALES

- ATELIERS, BANDES VIDÉOS, PUBLICATIONS

PARRAINÉ PAR:

Forêts Canada et le Ministère des Richesses naturelles de l'Ontario grâce à

l'Entente Canada-Ontario sur la mise en valeur de la ressource forestière. Sous les auspices du Comité ontarien sur le recherche forestière.

Pour toute information concernant MARKETPLACE contactez:
Guy K.M. Smith

Forêts Canada, Région de l'Ontario

Centre de foresterie

des Grands Lacs

C.P. 490

Sault Ste-Marie, Ontario P6A 5M7

(705) 949-9461 / Fax: (705) 759-5700

\section{David Bates}

Ministère des Richesses naturelles

Institut ontarienne d'amélioration

des arbres et de la biomasse forestière

C.P. 7400

Maple, Ontario L6A 1S9

(416) 832-7279 / Fax: (416) 832-7179
Change of Address

Da:e

Section

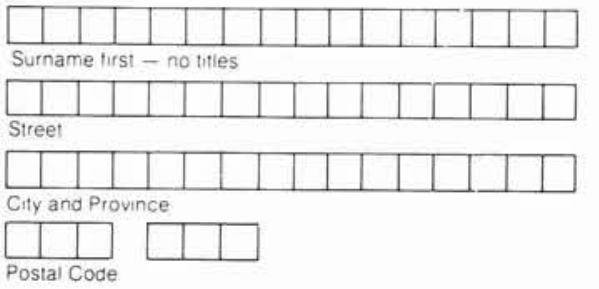

Changement d'adresse

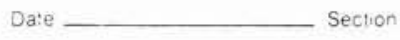

\section{Prenom en avant - pas de titres}

$$
\text { Rue }
$$

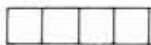

Ville et Province

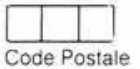

